\title{
TG wt Allele
}

National Cancer Institute

\section{Source}

National Cancer Institute. TG wt Allele. NCI Thesaurus. Code C52488.

Human T G wild-type allele is located in the vicinity of $8 \mathrm{q} 24$ and is approximately $268 \mathrm{~kb}$ in length. This allele, which encodes thyrog lobulin protein, plays a role in the mediation of thyroid hormone production. Mutations in the gene are involved in goiter formation and genetic variants are associated with autoimmune thyroid disease type 3. 